\author{
1,Sukamta, ${ }^{2}$ Widyasmoro, ${ }^{3}$ Fitri \\ Wahyuni, "Cahyo Budiyantoro \\ ${ }^{5}$ Muhammad Agung As'ari, 'Tiara Cahya \\ Atikasari, ${ }^{7}$ Nurhalizah Agustina, \\ ${ }^{8}$ Yudani Alamsyah Harahap \\ ${ }^{1,4}$ Program Studi Teknik Mesin, Fakultas \\ Teknik Universitas Muhammadiyah \\ Yogyakarta \\ 2, ${ }^{6}$ Program Studi Teknik Elektro, Fakultas \\ Teknik Universitas Muhammadiyah \\ Yogyakarta \\ ${ }^{3}$ Program Studi Akuntansi, Fakultas \\ Ekonomi dan Bisnis Universitas \\ Muhammadiyah Yogyakarta \\ ${ }^{5}$ Program Studi Teknik Sipil, Fakultas \\ Teknik Universitas Muhammadiyah \\ Yogyakarta \\ ${ }^{7}$ Program Studi Akuntansi, Fakultas \\ Ekonomi dan Bisnis Universitas \\ Muhammadiyah Yogyakarta \\ ${ }^{8}$ Program Studi Agribisnis, Fakultas \\ Pertanian Universitas Muhammadiyah \\ Yogyakarta \\ Jalan Brawijaya,Tamantirto, Kasihan, \\ Ngaglik, Sleman, Yogyakarta, Indonesia. \\ Email : sukamta@umy.ac.id
}

\section{Pemanfaatan Limbah Kotoran Sapi untuk Produksi Batu Bata Ramah Lingkungan dan Tahan Gempa}

\author{
Cow Dung Waste Utilization For The Production Of Environ- \\ mentally Friendly And Earthquake Resistant Brick
}

https://doi.org/10.18196/bdr.8172

\begin{abstract}
Cow dung waste at Srunen hamlet, Glagaharjo village, Cangkringan, Sleman is recorded to be high in quantity since it also has a high population of dairy cows. The high volume of cow dung waste leads to environment pollution, either water or air pollution. The environment pollution it causes may further trigger some problems regarding society's health, safety and comfort. Thereby, the abundant quantity of cow dung waste needs to be well-managed and oriented for economics. One of among other technologies to manage cow dung waste which had never been implemented before is to utilize the waste as the raw material component of brick. Such brick production technology is not only environmentally friendly but is also resistant toward earthquake. This technology was introduced and implemented during the Community Service program at Glagaharjo village. The program was implemented through the methods of assessment and education, as well as feasibility test. Training and practice were conducted to adopt the technology of environmentally friendly and earthquake resistant cow dung brick. Further, the product was tested for its feasibility as construction material. The success of the program is shown from the society's ability to produce the environmentally friendly and earthquake resistant brick which has also increased society's income and the hamlet's economy.

Keyword: dung waste, cow cattle, brick, income, economy
\end{abstract}

\title{
PENDAHULUAN
}

Batu bata merupakan salah satu bahan material sebagai bahan pembuat dinding. Batu bata terbuat dari tanah lempung yang dibakar sampai berwarna kemerah-merahan. 
Memilih batu bata sebagai bahan pembuat dinding memang cukup beralasan. Hal ini dikarenakan batu bata memiliki keunggulan yaitu, bahan utama batu bata yang merupakan tanah liat mudah didapat dengan persediaan yang cukup; sehingga menyebabkan harga batu bata cukup murah. Selain karena bahan baku yang mudah didapat, batu bata juga mudah dibuat. Hanya membutuhkan alat-alat sederhana dan modal yang kecil sehingga banyak masyarakat yang dapat membuat dan persediaan batu bata menjadi mudah diperoleh. Batu bata tahan terhadap cuaca panas, cuaca dingin, dan udara lembab. Hal inilah yang diharapkan mampu diberikan dinding sebagai salah satu pelindung rumah. Karena sifatnya yang mampu menolak panas, batu bata sangat cocok untuk dijadikan tembok rumah. Batu bata mampu membuat kondisi atau suhu di dalam rumah terasa dingin walau di luar rumah cuaca panas.

Untuk dapat memenuhi kebutuhan batu bata seiring dengan peningkatan jumlah dan laju perkembangan penduduk, produksi batu bata pun harus ditingkatkan, bukan hanya dalam segi jumlah melainkan juga mutu. Adapun batu bata yang tersedia umumnya ternyata memberikan banyak keluhan khususnya untuk para pekerja konstruksi yang merasa bahwa batu bata yang ada terlalu kecil sehingga memerlukan waktu lama serta cukup menguras tenaga dalam proses penyelesaian pekerjaan konstruksi tersebut. Namun, apabila menggunakan batu bata yang berukuran besar dapat memakan biaya yang cukup besar karena lebih mahal. Selain itu, kualitas batu bata merah yang tersedia umumnya mudah retak dan hancur akibat kurang kualitas batu bata yang dihasilkan. Maka dari itu, dalam pembuatan batu bata perlu adanya peningkatan mutu yang dihasilkan secara efektif. Untuk mengurangi dampak negatif yang terjadi tersebut, diberikan suatu solusi. Seiring perkembangan teknologi saat ini, mulai banyak melakukan inovasi yang membantu memperbaiki mutu dan kualitas batu bata yang dihasilkan.

Bahan material dinding terus berkembang seiring dengan tuntutan kebutuhan dalam mencapai biaya, waktu, dan mutu yang paling efektif dan efisien. Munculnya teknologi bata ringan sebagai material dinding, cukup memberikan dampak positif bagi masyarakat pada umumnya dan dunia konsruksi pada khususnya. Penelitian juga telah dilakukan untuk memberikan perbandingan harga material, kecepatan, dan berat antara bata merah dengan bata ringan untuk pekerjaan pasangan dinding, mulai dari material untuk pekerjaan pemasangan, plesteran, hingga acian. Harga material pekerjaan pasangan bata ringan lebih mahal 1,18x dibandingkan dengan harga material pekerjaan pasangan bata merah (Suseno, Prastumi, Susanti, \& Setyowulan, 2012). Penelitian dengan memanfaatkan abu sisa pembakaran limbah kayu sebagai bahan dalam campuran batu bata juga telah 


\section{5}

dilakukan. Penelitian ini dilakukan dengan mencampur sisa abu dengan tanah lempung proporsi $0 \%, 5 \%, 10 \%, 15 \%, 20 \%$ dan $25 \%$. Dari hasil campuran dilakukan pengujian karakteristik campuran yaitu kuat tekan dan rembesan air. Hasil penelitian menunjukkan bahwa abu sisa pembakaran limbah kayu dapat dipakai sebagai bahan dalam pembuatan batu bata dengan kualitas yang masih memenuhi persyaratan (I Made Nada, dkk., 2010). Penelitian batu bata merah dengan penambahan campuran limbah serbuk gergaji telah dilakukan. Variabel dalam penelitian ini adalah standar kualitas batu bata merah yang meliputi pandangan luar (bentuk, warna), berat, ukuran, kuat tekan, kandungan kadar garam, dan penyerapan air dan bobot isi. Hasil penelitian menunjukkan bahwa penambahan serbuk gergaji 10\% tidak menunjukkan perbedaan yang signifikan dengan batu bata tanpa penambahan serbuk gergaji. Oleh karena itu, serbuk gergaji sebagai limbah penggergajian kayu dapat dimanfaatkan sebagai bahan campuran dalam pembuatan batu bata dengan persentase penambahan 10\% (Handayani, 2010).

Penelitian yang mensubstitusi semen dengan lumpur Lapindo dalam konteks volume telah dilakukan untuk mengetahui komposisi adukan yang paling ideal bila ditinjau dari segi kuat tekan dan penyerapan air dari bata beton pejal. Dalam penelitian ini, dibuat 5 jenis adukan dengan variasi PC mulai 100\% hingga 30\% dan Lumpur Lapindo mulai 0\% hingga 30\%. Perbandingan berat antara PC dengan pasir adalah 1:-8 dengan faktor air semen 0,4 . Semen yang digunakan dalam penelitian ini adalah semen Gresik dengan benda uji dites dalam umur 28 hari. Bila ditinjau dari segi penyerapan air, hasil dari penelitian ini menunjukkan bahwa penggunaan lumpur Lapindo sebagai bahan substitusi semen sebesar 24,56\% mampu menurunkan persentase penyerapan air secara optimum yaitu sebesar $18,21 \%$ dan menghasilkan kuat tekan sebesar $71,5 \mathrm{~kg} / \mathrm{cm} 2$. Yang termasuk dalam mutu B1. Hal ini disebabkan oleh besarnya kandungan $\mathrm{SiO} 2$ (berfungsi sebagai bahan pengisi) yang juga mesti didukung kandungan $\mathrm{CaO}$ yang berfungsi menjaga keterikatan antamaterial. Kecilnya nilai penyerapan air juga dapat meningkatkan ketahanan (durability) dari bata beton pejal. Bila ditinjau dari segi kuat tekan, penggunaan lumpur Lapindo sebesar 7,25\% dapat menghasilkan bata beton pejal dengan mutu B2. Pada adukan ini, kuat tekan yang dihasilkan sebesar $100,1 \mathrm{~kg} / \mathrm{cm} 2$ dan persentase penyerapan air sebesar 20,72\% (Anom Wiryasa dan Sudarsana, 2009).

Lumpur Lapindo Sidoarjo sangat cocok untuk material dasar keramik seperti genteng, bata, dan hiasan (Karimah, 2008). Karimah menyatakan bahwa pemanfaatan lumpur Lapindo agar lebih maksimal menggunakan persentase campuran lumpur Lapindo di atas 35\% dengan menambahkan bahan tambahan seperti abu sekam. Dengan demikian, 
kemudian dilakukan penelitian pengaruh komposisi lumpur Lapindo Sidoarjo terhadap syarat mutu batu bata berdasarkan SNI 15-2094-2000. Penelitian ini bersifat eksperimen dengan variabel bebas terdiri atas persentase lumpur Lapindo mulai dari 35 sampai dengan 55\%, sedangkan variabel kontrolnya adalah mutu batu bata berdasarkan SNI 15-2094. 2000. Dapat disimpulkan bahwa tidak ada batu bata berbahan lumpur Lapindo Sidoarjo yang memenuhi keseluruhan syarat SNI 15-2094-2000. Namun, batu bata dengan komposisi 40\% lumpur Lapindo Sidoarjo cukup baik untuk digunakan sebagai campuran batu bata, sebab benda uji $\mathrm{C}$ tersebut hanya tidak memenuhi syarat uji penyerapan air (Niam, 2016). Upaya untuk meningkatkan nilai tambah kotoran sapi, sudah dilakukan dengan menjadikan kotoran sapi menjadi produk pupuk organik yang bernilai komersial di Dusun Kalipucang, Bangunjiwo, Bantul Yogyakarta. Kegiatan pengelolaan limbah kotoran sapi menjadi pupuk organik ini sangat bermanfaat bagi masyarakat dan mampu meningkatkan kemampuan ekonomi masyarakat dengan nilai benefit cost ratio 6,67 dan pay back period 5,07 bulan (Sukamta, Shomad, dan Wisnujati, 2017).

Desa Glagaharjo merupakan salah satu desa yang sebagian besar penduduknya merupakan peternak sapi perah. Namun, dikarenakan masyarakat yang bermata pencaharian sebagai petani cukup minim, maka limbah kotoran sapi ini menjadi permasalahan lingkungan yang ada di dusun ini. Menurut data dan hasil wawancara bersama warga, satu ekor sapi setiap harinya menghasilkan $25 \mathrm{~kg}$ kotoran sapi, jika minimal terdapat 3 ekor sapi maka minimal dalam setiap rumah terdapat minimal $75 \mathrm{~kg}$ limbah kotoran sapi setiap harinya. Masyarakat mengaku sudah memanfaatkan limbah kotoran sapi yang digunakan sebagai pupuk untuk menutrisi tanaman yang ada di pekarangan rumah warga masing-masing. Dengan demikian, masih cukup banyak sisa limbah kotoran sapi yang belum dimanfaatkan.

Limbah kotoran sapi yang cukup melimpah memiliki beberapa dampak secara langsung. Dampak yang ditimbulkan oleh limbah kotoran sapi ini adalah adanya pencemaran karena gas metan menyebabkan bau yang menyengat bagi lingkungan sekitar. Gas metan $\left(\mathrm{CH}_{4}\right)$ berasal dari proses pencernaan ternak ruminansia. Gas metan ini adalah salah satu gas yang bertanggung jawab terhadap pemanasan global dan perusakan ozon, dengan laju $1 \%$ per tahun dan terus meningkat. Feses dan urine dari hewan dapat menjadi media penularan penyakit, misalnya penyakit anthrax melalui kulit manusia yang terluka atau tergores.

Dari permasalahan tersebut, diusulkan solusi dalam bentuk program pengabdian kepada masyarakat di sebuah desa dengan tingkat populasi sapi yang cukup tinggi dengan 
limbah kotoran sapi yang melimpah juga, yaitu "Pemanfaatan Limbah Kotoran Sapi Menjadikan Desa Glagaharjo sebagai Desa Mandiri Produsen Batu Bata Ramah Lingkungan dan Tahan Gempa” di Dusun Srunen, Desa Glagaharjo, Kecamatan Cangkringan, Kabupaten Sleman, Yogyakarta.

\section{METODE PELAKSANAAN}

Untuk menjawab permasalahan-permasalahan lingkungan dan pengembangan ekonomi yang dihadapi oleh mitra kami, solusi yang ditawarkan pada kegiatan Program Pengembangan Desa Mandiri (PPDM) ini, meliputi bidang lingkungan antara lain melalui a) pendataan jumlah total sapi di Desa Glagaharjo, b) pengembangan peternakan bersih dengan pengadaan storage atau tempat pembuangan limbah kotoran sapi, dan c) pelatihan pengolahan pemanfaatan limbah kotoran sapi menjadi batu bata. Pada bidang ekonomi, kegiatan ini melibatan dua kelompok usaha batu bata desa Glagaharjo, yaitu a) pelatihan kewirausahaan kepada masyarakat tentang manajemen kewirausahaan produk batu bata dan, b) pendampingan pemasaran online untuk perluasan pemasaran produk-produk dari mitra. Hasil keseluruhan dan luaran yang diharapkan dari kegiatan PPDM ini adalah terwujudnya pengelolaan dan pengembangan desa mandiri yang lebih sehat, pengelolaan peternakan yang bersih, dikembangkan hasil dari limbah kotoran sapi yang produktif sehingga limbah kotoran sapi dapat dimanfaatkan menjadi produk yang bernilai jual di masyarakat yaitu batu bata yang ramah lingkungan dan tahan/ramah gempa. Program Pengembangan Desa Mitra ini mengunakan pendekatan RRA (Rapid Rural Appresial) / PRA (Partisipatori Rural Appresial) / RRA dan PRA adalah falsafah; pendekatan metode yang dikenal sebagai upaya memahami desa secara cepat.A-dapun prinsip-prinsip pendekatan RRA dan PRA yang dipakai dalam kegiatan ini adalah-: 1) Belajar secara Cepat dan Progresif, melalui eksplorasi yang terencana, pemakaian metode yang fleksibel, improvisasi, pengulangan dan menyesuaikan dengan proses belajar atau pemahaman. 2) Optimalisasi Pertukaran, mengkaitkan biaya pemahaman dengan informasi yang benarbenar bermanfaat bagi masyarakat di Desa Glagaharjo, Kecamatan Cangkringan, Kabupaten Sleman dengan pertukaran antar-kuantitas, kegayutan, keakuratan dan ketepatan waktu. 3) Pemberian fasilitas, artinya memberikan fasilitas penyelidikan, analisis , penyajian dan pemahaman oleh masyarakat di wilayah Desa Glagaharjo, Kecamatan Cangkringan, Kabupaten Sleman, sehingga mereka dapat menyajikan dan memiliki hasilnya, dan juga mempelajarinya. 4) Kesadaran dan tanggung jawab diri yang kritis, artinya Fasilitator secara terus-menerus menguji tingkah laku mereka dan mencoba 
melakukannya secara lebih baik. 5). Saling berbagi informasi dan gagasan antar-masyarakat di Desa Glagaharjo, Kecamatan Cangkringan, Kabupaten Sleman dengan fasilitator, dan antar-fasilitator yang berbeda, serta saling berbagi wilayah kegiatan, pelatihan dan pengalaman antar organisasi yang berbeda. Kegiatan - kegiatan di atas direncanakan dilakukan dengan Focus Group Discussion (FGD), pelatihan, pendampingan dan diakhiri dengan evaluasi dan monitoring.

Jika mengacu pada rencana pengolahan limbah kotoran sapi yang belum termanfaatkan dengan optimal, potensi untuk menjadikan batu bata dari limbah kotoran sapi ini sangat besar potensialnya. Di samping penggunaan material "limbah" yang sangat dibutuhkan ntuk mengurangi penggunaan material yang tak terbarukan. Kebutuhan batu bata terus meningkat tiap tahunnya sehingga produsen batu bata tidak mampu memenuhi kebutuhan pasar. Berdasarkan kondisi tersebut, batu bata ini mempunyai peluang yang besar untuk masuk di pasaran. Karena limbah kotoran sapi memiliki kandungan seperti semen, bata yang dihasilkan dari campuran kotoran sapi akan lebih kuat dan ringan sehingga akan meningkatkan daya jual produk batu bata ini. Untuk itu, kegiatan yang dilakukan dalam memanfaatkan limbah kotoran sapii Desa Glagaharjo adalah sebagai berikut: 1)- Setiap warga yang memiliki sapi akan diidentifikasi berapa banyak limbah yang dihasikan, apakah di bawah $6 \mathrm{~m}^{3}$, atau di atas $6 \mathrm{~m}^{3}$ sehingga akan menjadi dasar seberapa sering pengangkutan dalam seminggu. 2)- Membuat storage untuk penampungan limbah kotoran sapi sementara, setiap RW akan diberikan 3 penampungan limbah dengan kapasitas setiap penampungan $3000 \mathrm{~kg}$ limbah. 3)- Membuat maping untuk giliran pengangkutan kotoran sapi (minimal seminggu satu kali per kepala keluarga). 4)- Warga diberi pelatihan untuk penyimpanan limbah kotoran sapi agar cepat kering sehingga dapat dimanfaatkan untuk pembuatan batu bata. 5- Setiap hari akan ada pengangkutan kotoran sapi kering untuk di-antarkan ke rumah produksi (sesuai giliran pada maping). 6Bagaimana proses pembakaran batu bata yang efektif dan efisien dengan suhu sekurangkurangnya $300^{\circ} \mathrm{C}$ selama 1,5 hari sampai 3 hari agar batu bata memiliki tingkat kekerasan yang memenuhi standar.

\section{HASIL DAN PEMBAHASAN}

Hasil pelaksanaan pengabdian kepada masyarakat dapat ditunjukkan pada gambar 1 sampai dengan gambar 10 berikut ini. Pada gambar 1. dapat diketahui peta lokasi Desa Srunen yang terletak kurang lebih $25 \mathrm{~km}$ atau 1 jam 6 menit perjalanan dari Kampus Universitas Muhammadiyah Yogyakarta. 


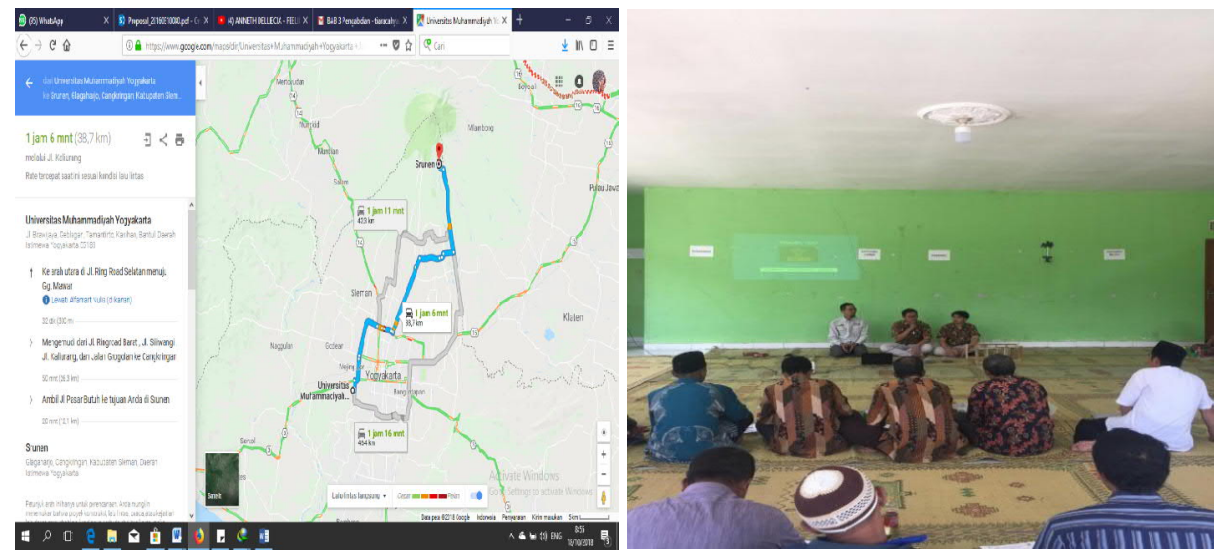

Gambar 1. Peta Lokasi Pengabadian dari Kampus UMY Gambar 2. Kegiatan Sosialisasi
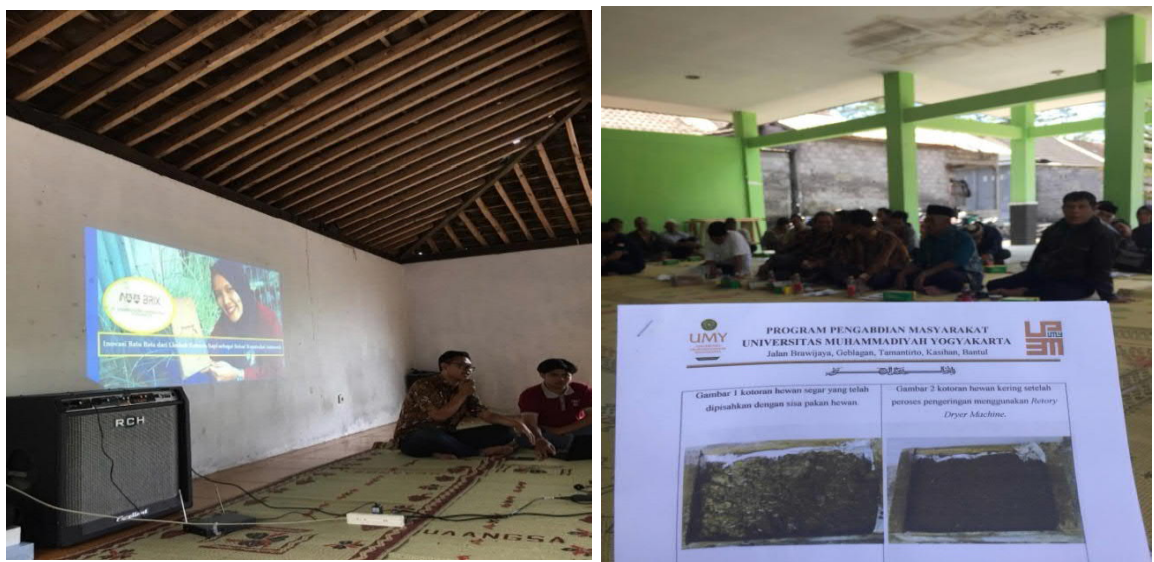

Gambar 3. Kegiatan Presentasi Desain Kegiatan Gambar 4. Kegiatan Persiapan Pelaksanaan

Sementara itu, gambar 2, 3, dan 4 menjelaskan kegiatan sosialisasi, presentasi desain, dan persiapan pelaksanaan pengabdian kepada masyarakat ini. Gambar 5 menjelaskan kegiatan persiapan bahan meliputi kotoran sapi dan tanah liat dengan perbandingan $30 \%$ dibanding $70 \%$ tanah liat. Kegiatan pencampuran bahan dijelaskan pada gambar 6 , yaitu dengan menambahkan air secukupnya pada campuran kotoran sapi dan tanah liat tersebut. Sementara gambar 7 menggambarkan proses pencetakan dan pengeringan batu bata dengan sinar matahari. Monitoring terhadap hasil cetakan dilakukan secara periodik seperti ditunjukkan pada gambar 8 . Setelah batu bata dinilai sudah kering, kemudian dilakukan proses pembakaran sehingga menghasilkan batu bata merah seperti ditunjukkan pada gambar 9 . 


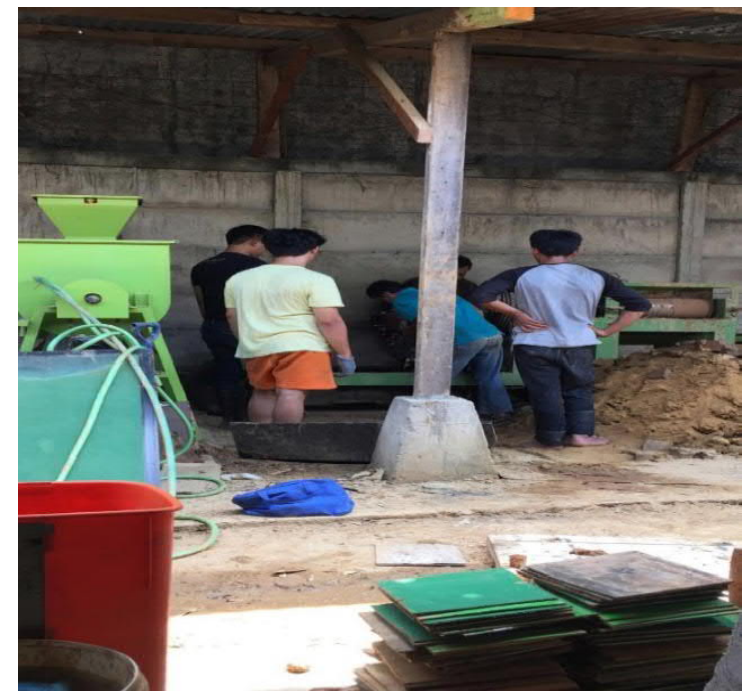

Gambar 5. Kegiatan Persiapan Bahan

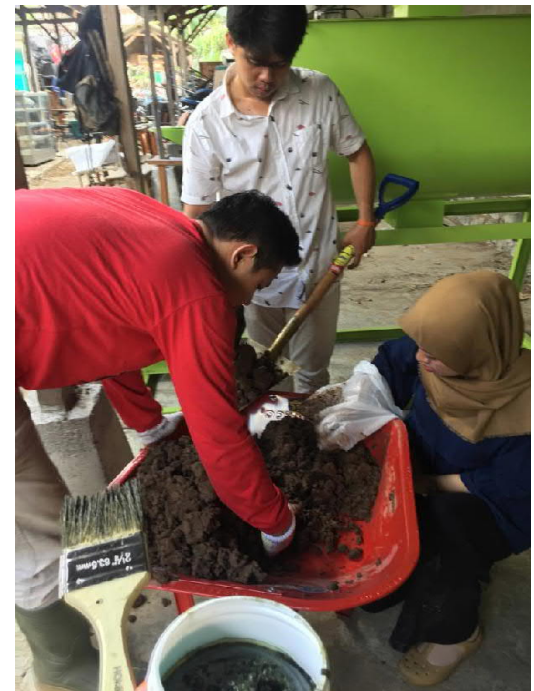

Gambar 6. Kegiatan Pencampuran Bahan

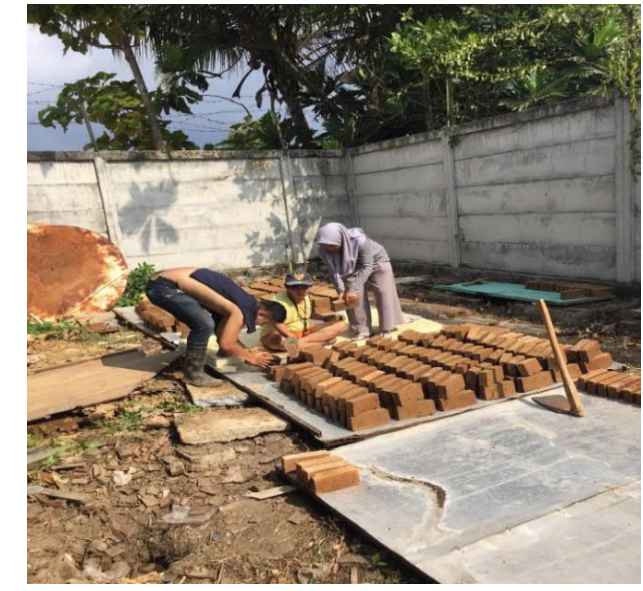

Gambar 7. Kegiatan Proses Pencetakan Batu Bata

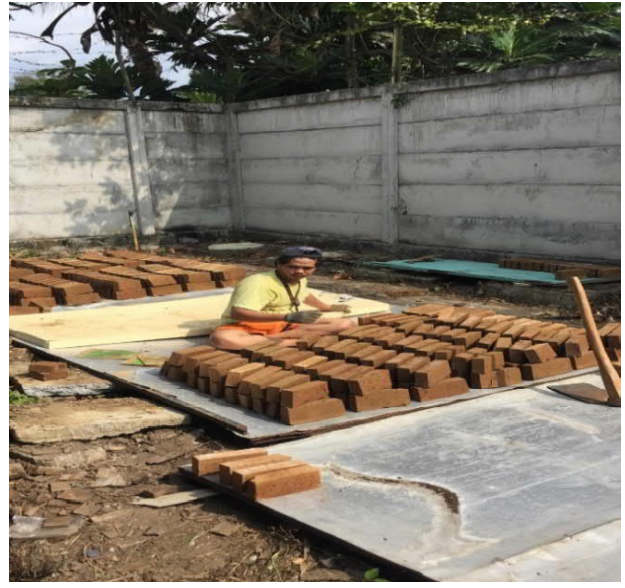

Gambar 8. Kegiatan Monitoring Hasil Cetakan

Sampai saat ini, batu bata meraih hasil dari kotoran sapi ini telah diproduksi kurang lebih 5000 dengan ukuran $20 \mathrm{~cm}$ x $5 \mathrm{~cm}$ x $10 \mathrm{~cm}$. Jika ditinjau dari beratnya, kegiatan pengabdian kepada masyarakat telah berhasil membuat berat batu bata dari limbah kotoran sapi ini turun sekitar 30\% dibanding dengan batu bata yang terbuat dari tanah liat secara penuh, sehingga menjadikan batu bata ini relatif tahan terhadap gempa dan juga ramah terhadap lingkungan. Hasil ini masih dapat ditingkatkan sehingga mutu batu bata merah dengan campuran kotoran sapi ini dapat meningkat. Dari hasil tes uji kekerasan dapat diketahui nilai kuat tekan rata-rata $7.2 \mathrm{~kg} / \mathrm{cm}^{2}$. Untuk saat ini, hasil uji kekerasan tersebut masih jauh dari harapan, sehingga masih harus terus ditingkatkan sampai memenuhi persyaratan Standar Nasional Indonesia (SNI) agar dapat dipasarkan di masyarakat luas. Sementara ini, hasil batu bata dari kotoran sapi ini masih dipasarkan untuk kalangan sendiri atau terbatas. 


\section{1}

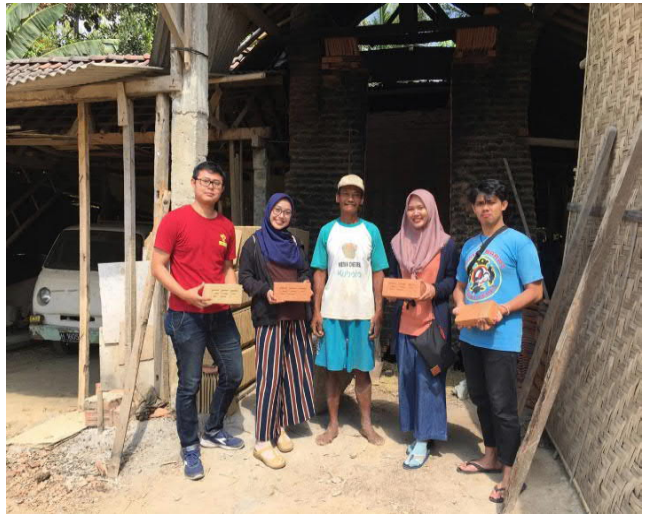

Gambar 9. Batu Bata Setelah Proses Pembakaran

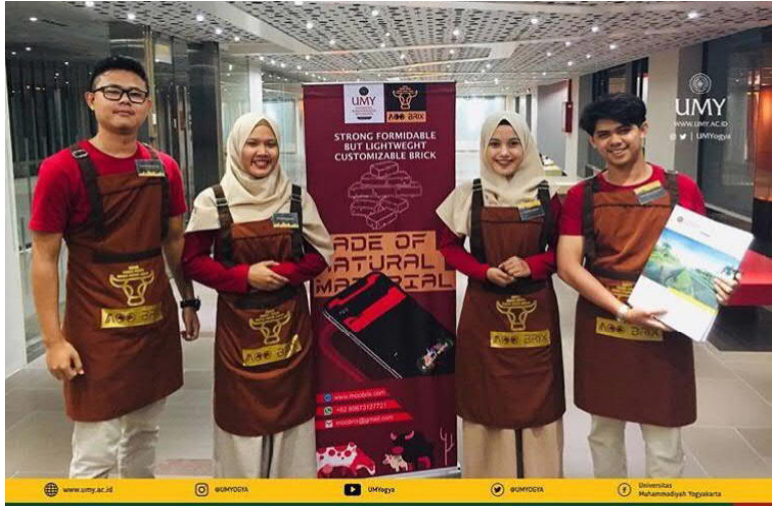

Gambar 10. Kegiatan Iklan Pemasaran Batu Bata

Peneliti sebelumnya telah melakukan penelitian dengan memanfaatkan limbah abu sekam padi dan serbuk batu-tabas yang ditambahkan dengan semen sebagai perekat dan dicampur dengan tanah liat serta tanpa mengalami proses pembakaran. Berdasarkan penelitian tersebut diperoleh informasi bahwa nilai kuat tekan terbesar batu bata tanpa pembakaran adalah $22,90 \mathrm{~kg} / \mathrm{cm} 2$ yang diperoleh dari campuran abu sekam dan serbuk batu tabas 30\% dan 0\% pada umur 28 hari (Sudarsana, Budiwati,-dan Wijaya, 2011). Pada sisi lain, penelitian pengaruh bottom ash sebagai pengganti tanah liat terhadap kuat tekan bata telah dilakukan. Pengujian dilakukan dengan membuat benda uji bata dengan variasi persentase tanah liat dan bottom ash. Setelah itu, dilakukan uji tekan untuk mengetahui kekuatan tekan bata serta pengaruh dari pemakaian bottom ash. Mengacu pada hasil pengujian, diketahui bahwa penggunaan bottom ash sebagai pengganti tanah liat dengan perssentase maksimum 45\% dapat menghasilkan batu bata dengan kuat tekan yang sama atau lebih dari batu bata yang menggunakan tanah liat 100\% (Suseno et al., 2012). Pada penelitian sebelumnya, juga telah dilakukan pembuatan bata ringan dengan komposisi semen dan abu terbang masing-masing 50\% serta campuran foam, polimer, dan hardener masing-masing 0,50\% memperoleh hasil rata-rata kuat tekan bata ringan yang paling tinggi sebesar $39,99 \mathrm{~kg} / \mathrm{cm}^{2}$ atau 3,92 Mpa, sedangkan berat jenisnya diperoleh $0,78 \mathrm{~kg} / \mathrm{dm}^{3}$ atau $780 \mathrm{~kg} / \mathrm{m}^{3}$. Hasil uji tersebut masih memenuhi syarat SNI 03-0349-1989, yaitu $21 \mathrm{~kg} / \mathrm{cm}^{2}$ untuk tingkat mutu IV bata beton pejal serta berat bata ringan yaitu menurut Tjokrodimuljo (2007), beton disebut ringan apabila beratnya kurang dari $1800 \mathrm{~kg} / \mathrm{m}^{3}$ (Haryanti, 2015).

Gambar 10 menjelaskan mengenai branding dan iklan batu bata dari kotoran sapi. Karena dengan branding yang baik dan metode pemasaran yang tepat ternyata telah menjadikan batu bata ini diminati terutama oleh PT. Umat Mandiri Berkemajuan yang kemudian memesan dalam jumlah banyak untuk digunakan keperluan tamanisasi. 
Berdasarkan data primer yang diperoleh, satu ekor sapi setiap harinya menghasilkan 25 kg kotoran sapi. Setiap rumah di dusun ini rata-rata memiliki 3 ekor sapi sehingga minimal menghasilkan $75 \mathrm{~kg}$ limbah kotoran sapi setiap harinya. Dusun Srunen ini memiliki 2 Rukun Warga dan 4 Rukun Tetangga dengan jumlah rumah sekitar 172 rumah. Persentase penduduk yang bermata pencaharaian sebagai peternak 47,81\%. Dengan demikian, potensi penghasil limbah kotoran sapi sekitar 6,1 ton/hari basah atau sekitar 2 ton/hari kering. Berdasarkan potensi limbah kotoran sapi kering ini, batu bata yang dapat dihasilkan sekitar 8 ton batu bata/hari. Dengan demikian, pemanfaatan limbah kotoran sapi menjadi batu bata ini sangat potensial menjadikan desa ini khususnya Dusun Srunen menjadi mandiri secara ekonomi,

\section{SIMPULAN}

Kegiatan pendataan jumlah total jumlah sapi, pengembangan peternakan bersih, dan pelatihan pengolahan pemanfaatan limbah kotoran sapi menjadi batu bata telah berjalan dengan baik. Kegiatan ini juga membantu eksistensi kelompok usaha batu bata- sehingga mampu berwirausaha secara mandiri. Hasil dari kegiatan ini telah nyata dengan diproduksinya lebih dari 5000 batu bata kotoran sapi dan telah memenuhi persyaratan kelayakan pakai, relatif sesuai untuk bangunan tahap gempa yang ramah lingkungan, dan telah dipasarkan di kalangan terbatas. Inovasi dan penelitian pengembangan masih terus dilakukan untuk meningkatkan kualitas batu bata tersebut sehingga dihasilkan batu bata yang memiliki kekerasan memenuhi standar SNI agar mampu dipasarkan secara lebih luas.

\section{UCAPAN TERIMA KASIH}

Pengabdian Masyarakat ini dibiayai oleh Lembaga Penelitian, Publikasi, dan Pengabdian Kepada Masyarakat Universitas Muhammadiyah Yogyakarta dengan Surat Tugas no. 234/A.3-11l/LP3M/V /2019 tanggal 11 Mei 2019.

\section{DAFTAR PUSTAKA}

Anom Wiryasa, N., \& Sudarsana, I. (2009). Pemanfaatan Lumpur Lapindo Sebagai Bahan Substitusi Semen Dalam Pembuatan Bata Beton Pejal. Jurnal IImiah Teknik Sipil, 13(1), 39-46.

I Made Nada, Ida Bagus Suryatmaja. (2010). Jurnal ilmiah kurva teknik. 17-35.

Handayani, S. (2010). Kualitas Batu Bata Merah. Kualitas Batu Bata Merah, 12(Handayani Sri), 41-50.
Haryanti, N. H. (2015). Kuat Tekan Bata Ringan Dengan Bahan Campuran Abu Terbang PLTU Asam-Asam Kalimantan Selatan. Fisiki FLUX, 12, 20-30.

Sudarsana, I., Made Budiwati, I., \& Angga Wijaya, Y. (2011). Karakteristik Batu Bata Tanpa Pembakaran Terbuat Dari Abu Sekam Padi Dan Serbuk Batu Tabas. Jurnal IImiah Teknik Sipil, 15(1), 93-101. 
Sukamta, S., Abdus Shomad, M., \& Wisnujati, A.

(2017). Pengelolaan Limbah Ternak Sapi Menjadi Pupuk Organik Komersial di Dusun Kalipucang, Bangunjiwo, Bantul, Yogyakarta. BERDIKARI/ : Jurnal Inovasi dan Penerapan Ipteks, 5(1), 1-10. https://doi.org/10.18196/bdr.5113

Suseno, H., Prastumi, P., Susanti, L., \& Setyowulan, D. (2012). Pengaruh penggunaan bottom ash sebagai pengganti tanah liat pada campuran bata terhadap kuat tekan bata. Jurnal Rekayasa Sipil, 6(3), 264-271. Retrieved from http://

rekayasasipil.ub.ac.id/index.php/rs/article/view/ 226

Yazidun Niam, A. (2016). Pengaruh Treatment Lumpur Lapindo Terhadap Mutu Batu Bata Bahan Lumpur Lapindo Berdasarkan Sni 15-2094-2000. Rekayasa Teknik Sipil, 1(1/REKAT/17), 1-7. 